\title{
Procedural aspects of COVID-19 vaccinations for seafarers on ocean-going vessels
}

\author{
Clara C. Schlaich, Katharina Lucas, Sophia Sydow, Eike Beyer, Karl P. Faesecke
}

Hafenpraxis Dr. Schlaich and Dr. Beyer, Hamburg, Germany

\begin{abstract}
The increasing availability of safe and authorised coronavirus disease 2019 (COVID-19) vaccines for the first time provides the opportunity to vaccinate seafarers on board their ships while in port. Speedy vaccination of seafarers secures their health and serves to avoid the international propagation of COVID-19 virus variants via maritime traffic. As a port medical clinic, we will share our practical vaccination experience on board of merchant vessels in German/European ports with our esteemed coastal colleagues to stimulate their participation in this endeavour. You will have to adapt the procedure to your national particularities, otherwise please freely share the information with interested parties. Detailed guidance on COVID-19 vaccination in shipping and accompanying legal issues was published by the International Chamber of Shipping (www.ics-shipping.org).
\end{abstract}

(Int Marit Health 2021; 72, 3: 179-182)

Key words: procedural aspects, COVID-19, vaccinations for seafarers

\section{INTRODUCTION}

The increasing availability of safe and authorised coronavirus disease 2019 (COVID-19) vaccines for the first time provides the opportunity to vaccinate seafarers on board their ships while in port.

Speedy vaccination of seafarers secures their health and serves to avoid the international propagation of COVID-19 virus variants via maritime traffic.

As a port medical clinic, we will share our practical vaccination experience on board of merchant vessels in German/European ports with our esteemed coastal colleagues to stimulate their participation in this endeavour. You will have to adapt the procedure to your national particularities, otherwise please freely share the information with interested parties.

Detailed guidance on COVID-19 vaccination in shipping and accompanying legal issues was published by the International Chamber of Shipping (ICS): www.ics-shipping.org $[1,2]$.

In addition to the well-known information provided by the manufacturers on the application of vaccines and the recommendations of STIKO (the German Permanent Commission on Vaccination), these ICS guidelines provide a basis for all parties for the joint execution of vaccinations on board, in particular about issues of liability, data protection, safety and the voluntary nature of vaccination.

The responsible port health service, representing the medical authority of the port, must be informed about the start of vaccination activities in the port area.

A list of contacts of the port health services in Germany can be found on the website of the Working Group of the Coastal States for Ships Hygiene: www.hamburg.de/hu/ /arbeitskreis-kuestenlaender [3].

\section{RESPONSIBILITIES}

The vaccinators are responsible for:

- commissioning of vaccines and paraphernalia;

- storage, vibration-free transport of the vaccine adhering to the cold chain on board and the correct processing of the vaccine;

- if the responsible physicians direct other persons to transport the vaccine on board, it must be ensured

Dr. med. Clara C. Schlaich, MPH and Dr. med. Karl P. Faesecke, Hafenpraxis Dr. Schlaich and Dr. Beyer, Shanghaiallee 15-17, D-20457 Hamburg, Germany,

e-mail: schlaich@hafenpraxis-hamburg.de; mail@faesecke.com

This article is available in open access under Creative Common Attribution-Non-Commercial-No Derivatives 4.0 International (CC BY-NC-ND 4.0) license, allowing to download articles and share them with others as long as they credit the authors and the publisher, but without permission to change them in any way or use them commercially. 
that the vaccine is transported smoothly and stored in accordance with the cold chain. It is preferred to charge ship chandler pharmacies with delivering the vaccine on board, as they are familiar with the specific features of ports and ships;

- provision of information sheets and medical history to seafarers in advance; Robert-Koch-Institute (RKI) provides updated fact sheets in different languages [4]; the International Chamber of Shipping has written a general statement on COVID-19 for shipping to be made available to seafarers in advance [5];

- establishing vaccination indication or contraindication and individual information and counselling;

- one specific feature of seagoing vaccination is the assessment of heterologous vaccination schemes; seafarers have often received first vaccinations in other countries, sometimes with vaccines that are not authorised in the European Union. The vaccinators must check on a caseby-case basis whether a follow-up vaccination is indicated;

- implementation of vaccination with the appropriate paraphernalia;

- follow-up and treatment of acute vaccine complications;

- issuing a vaccination certificate;

- recording of vaccination information;

- notification of the dataset under the vaccination order to the RKI.

The remaining responsibility for the procedure on board remains with the shipping companies, the port agent, if applicable, and the master:

- prior registration of seamen willing to be vaccinated;

- providing name and address in CVS format (for the RKI);

- observance of data protection;

- advance information on previous vaccinations;

- keeping a list of reserve applicants to avoid waste of vaccines;

- distribution of information and consent sheets;

- reminder to bring along vaccination certificate and ID card;

- procedures regarding access to terminal/vessel for vaccinators;

- provision of support staff on board for follow-up of vaccinated;

- provision of ship's hospital/vaccination area and nearby follow-up space;

- provision of refrigerator with documented temperature control $\left(2-8^{\circ} \mathrm{C}\right)$;

- compliance with infection prevention during vaccination (distance rules, mouth-nose-protection);

- allow a rest period of 15-30 min after vaccination before return to work;

- rescue chain, securing the access of ambulance to the terminal/ship;

- communicating the voluntariness of vaccination.

\section{VACCINES}

All available COVID-19 vaccines in Germany can be applied for seafarers.

Janssen ${ }^{\odot}$ vaccine by Johnson \& Johnson is especially suited for the use on seafarers; it needs to be applied only once, it is easier to prepare on board and can be kept protected against light at $2^{\circ}$ to $8^{\circ}$ for up to 3 months after removal from the freezer.

In the European Union, the vaccine is authorised for persons aged 18 and over; based on the current data, the Permanent Commission on Vaccination at the Robert Koch Institute (STIKO) recommends that Johnson \& Johnson's vaccine Janssen ${ }^{\circledR}$ should normally be used for persons aged 60 and over.

The use of this vaccine as a one-time vaccination below this age limit is permitted based on medical information and individual risk acceptance by the vaccinee and makes sense in view of the above-mentioned advantage for seafarers in active employment.

If another vaccine is used, it should be possible for the shipping company to apply the second dose of the corresponding vaccine in the authorised time interval, if necessary, by postponing the entry into service on board. Follow-up vaccination is still possible even if the recommended time-lap is exceeded.

\section{DATA PROTECTION}

The seagoing population must be assured that vaccination remains a voluntary action and the employer does not have any access to the medical data of crew members. The medical history and consent sheets remain with the vaccinating physicians (the retention period is 10 years). The general data protection rules apply to the collection and processing of health data. Participation in vaccination mandates the notification of anonymized data by the responsible physician to the RKI.

\section{EQUIPMENT}

To be made available on board by the shipping company/master:

- suitable vaccination area, e.g. ship's hospital, office or mess-room;

- nearby waiting and observation area;

- seating accommodation for all vaccinated for 15-30 min, at least one berth;

- FFP2-/surgical masks for vaccinees;

- refrigerator with temperature control $2-8^{\circ} \mathrm{C}$;

- water/juice/soft drinks available.

To be brought by the vaccinating physicians:

- vaccines and paraphernalia;

- personal protective equipment;

- batch sticker, vaccination stamp, health certificate (in lieu of Vacc. Certif.). 
Table 1. Equipment for corona vaccinations on cargo ships

\begin{tabular}{|c|c|c|}
\hline & $\begin{array}{l}\text { Present on } \\
\text { ships (3) }\end{array}$ & Bring with doctor's bag \\
\hline Working mobile phone & & $\mathrm{x}$ \\
\hline Manual blood pressure meter & $x$ & \\
\hline Stethoscope & $x$ & \\
\hline Pulse-oximeter & $x$ & \\
\hline Pupillary light & $x$ & \\
\hline Tongue depressor & $x$ & \\
\hline $\begin{array}{l}\text { Intravenous fluid, e.g. } 500 \mathrm{cc} \mathrm{NaCl} 0.9 \% \text {, infusion set, } \\
\text { incl. i.v. cannula and fixed swabs }\end{array}$ & $x$ & $\begin{array}{l}\text { Preferably include in doctor's bag in } \\
\text { addition to supply on board }\end{array}$ \\
\hline Infusion stands or other suspension device & $x$ & \\
\hline Defibrillator & $x$ & \\
\hline Medical oxygen incl. mask & $x$ & \\
\hline Sharp waste disposal box & $x$ & \\
\hline Emergency medication for anaphylaxis & & $\begin{array}{l}\text { Preferably bring your own set of medica- } \\
\text { tion for readiness in case of emergency }\end{array}$ \\
\hline Epinephrine auto-injector or prefilled syringe & $x$ & $\mathrm{X} 2 \mathrm{pcs}$ \\
\hline Bronchodilator, e.g. salbutamol & $x$ & $x$ \\
\hline Antihistaminic tbl & $x$ & $x$ \\
\hline Antihistaminic amp & $x$ & $x$ \\
\hline Prednisolone tablets or fluid preparation & $x$ & $x$ \\
\hline Steroid i.v., e.g. $250 \mathrm{mg}$ prednisolone & $x$ & $x$ \\
\hline
\end{tabular}

Clearance for passing through restricted port areas and access to the ship must be provided by the ship-owner, ship agent or master in advance.

\section{EMERGENCY MEDICAL KIT}

Medical materials must be available for treatment of vaccine reactions, in particular allergic reactions, in accordance with guidelines [6, 7].

Sometimes the ship's pharmacy may be accessed in part [8].

Before commencing vaccination, the vaccinating physicians must ensure that the necessary equipment on board is operational, e.g. the semi-automatic defibrillator or medical oxygen. To this end, a prior visit to the ship's hospital will take place, together with the nautical officer responsible for medical care, applying the check-list below. The medication for the treatment of anaphylactic emergencies is brought on board in their emergency set by the vaccinating physicians (Table 1).

\section{PROTECTIVE EQUIPMENT FOR VACCINATORS}

- Depending on the terminal traffic situation: rotating warning light for the car;

- Safety shoes, at least closed footwear with non-slip sole;

- Protective helmet, size adjustable;
- Safety jacket (reflective);

- Protective gloves;

- Rescue vest as appropriate;

- Mobile phone/hands-free system in the car;

- Sufficient transportation bags for vaccines and emergency equipment (preferred rucksack to keep hands free);

- Single-use gloves, FFP2 mask.

\section{TIME ASSESSMENT}

- Travelling from office to terminal: to be determined...;

- Individual voyage from terminal entrance to ship: 30-60 min;

- Establishment of the vaccination area, getting to know the location, assessment of emergency equipment: $30 \mathrm{~min}$;

- Vaccination: 5 persons/hour, up to 10/h;

- Follow-up: 15-30 min/person.

Conflict of interest: None declared

\section{REFERENCES}

1. International Chamber of Shipping: () Coronavirus (COVID-19) Roadmap for Vaccination of International Seafarers Published by Marisec Publications Version 1.0 - May 2021. www.ics-shipping. org (11.7.2021).

2. International Chamber of Shipping: (c) Coronavirus (COVID-19) Legal, Liability and Insurance Issues arising from Vaccination of Seafarers 
Published by Marisec Publications 38 St Mary Axe London EC3A 8BH Version 1.

3. Coastal States Working Group on Ships Hygiene. www.hamburg.de/ hu/arbeitskreis-kuestenlaender (11.7.2021).

4. Robert-Koch Institute: Vaccination awareness sheets. https://www. rki.de/DE/Content/Infekt/Impfen/Materialien/COVID-19-Aufklaerungsbogen-Tab.html (11.7.2021).

5. International Chamber of Shipping: ๑ Coronavirus (COVID-19) Vaccination for Seafarers and Shipping Companies: A Practical Guide Your Questions Answered - 2021. www.icsshipping.org (11.7.2021) www.ics-shipping.org/wp-content/
uploads/2021/03/Coronavirus-COVID-19-Vaccination-forSeafarers-and-Shipping-Companies-A-Practical-Guide.pdf (11.7.2021).

6. Ring J, Beyer K, Biedermann T, et al. Guideline (S2k) on acute therapy and management of anaphylaxis: 2021 update. Allergo J Int. 2021; 30(1): 1-25, doi: 10.1007/s40629-020-00158-y.

7. www.cdc.gov/vaccines/covid-19/clinical-considerations/managing-anaphylaxis.html (11.7.2021).

8. Committee on Maritime Medical Equipment SDdBV. Changes in medical equipment on German seagoing vessels. 18 June 2021. www.deutsche-flagge.de (11.7.2021). 